\title{
Measurement of bilirubin, cholesterol and creatinine in serum and plasma, by solid-phase reflectance spectroscopy
}

\author{
JF STEVENS, W TSANG, RG NEWALL* \\ From the Department of Chemical Pathology, Middlesex Hospital Medical School, London and *Miles \\ Laboratories Limited, Stoke Poges, Slough
}

SUMMARY The Seralyzer chemistries for total bilirubin, cholesterol, and creatinine have been examined in the routine hospital laboratory, and have demonstrated good correlation and precision when compared to established routine methodologies. The system has proved to be reliable and easy to use.

Reflectance spectroscopy is being used increasingly in the field of clinical chemistry for the measurement of various analytes in blood. Its use in conjunction with solid-phase reagents makes the system versatile, and extends its applications to areas beyond that of clinical chemistry laboratories, who are dependent on the conventional wet chemistry techniques. This is available as the Seralyzer ${ }^{\mathrm{TM}}$ system (Ames Division, Miles Laboratories Limited). The system can provide a "Stat" function for the provision of urgent results, often extending the repertoire of tests available in this way.

Studies have already shown the suitability of the system for the routine measurement of glucose, urea and uric acid ${ }^{12}$ and a preliminary study on the measurement of bilirubin has also been made. ${ }^{3}$ Recently, Seralyzer methods have been developed for the measurement of total bilirubin, cholesterol, and creatinine, in serum. These have been studied to assess the performance in routine clinical use in the hospital laboratory, and were found to be convenient and reliable for routine clinical analysis.

\section{Material and methods}

THE SERALYZER SYSTEM

The Seralyzer system basically comprises a microprocessor-controlled reflectance photometer in association with dedicated solid-phase reagent strips, as briefly outlined previously. ${ }^{2}$ The principles of the system are described by Zipp. ${ }^{4}$

Modules are supplied for each test parameter.

Dr JF Stevens present address: St. Stephen's Hospital, Chelsea, London, SW10 9TH.

Accepted for publication 22 December 1982
These contain the correct filters for the chemical reactions taking place on the strip; a programme providing for calibration and test readings, and conversion to the appropriate concentration units; defined tolerance limits for acceptance of the calibration procedure; display of error codes, in the event of system faults; and a recognition system for the identification of the correct reagent strip for each test by means of bar codes on each strip. All tests are performed at a temperature of $37^{\circ} \mathrm{C}$. Tests are performed either as rate or end-point reactions, in the ultraviolet or visible regions of the spectrum. The two-point calibration is stored in the memory, so that constant recalibration is unnecessary.

\section{CHEMICAL PRINCIPLES}

Total bilirubin

The test is based on the reaction between bilirubin and a diazonium salt in the presence of dyphylline 을 and $p$-toluene sulphonic acid, the end-product being the red-purple coloured substance azobilirubin.

The test requires $30 \mu$ l of undiluted serum. After an incubation period of $75 \mathrm{~s}$, the concentration of $\sigma$ serum total bilirubin is determined by measuring the $N$ change in reflectance at $560 \mathrm{~nm}$ with reference to a calibration curve.

\section{Cholesterol}

The Seralyzer cholesterol reagent strip is based on $\stackrel{\mathbb{Q}}{9}$ the reaction in which the hydrogen peroxide, gener- $\square$ ated in the cholesterol oxidase reaction, is measured by the oxidative coupling of $3-\stackrel{\mathbb{D}}{\circ}$ methyl-2-benzothiazolinone hydrazone (MBTH) $\stackrel{\mathbb{Q}}{\mathbb{Q}}$ and primaquine disphosphate in the presence of $\frac{\sigma}{\sigma}$ 598 
cholesterol esters are hydrolysed to cholesterol in the presence of cholesterol ester hydrolase. The test requires $30 \mu \mathrm{l}$ of ninefold diluted serum. After an incubation period of $135 \mathrm{~s}$, the concentration of serum cholesterol is determined by measuring the reflectance at a wavelength of $600 \mathrm{~nm}$.

\section{Creatinine}

The Seralyzer creatinine reagent strip method is based on the Benedict-Behre reaction, in which creatinine reacts with 3,5-dinitrobenzoic acid (DNBA) in an alkaline medium to form a purplecoloured complex. Thirty microlitres of undiluted specimen is required. Formation of the coloured complex is monitored by the Seralyzer at $560 \mathrm{~nm}$, with measurements taken at five-second intervals between 15 and $30 \mathrm{~s}$.
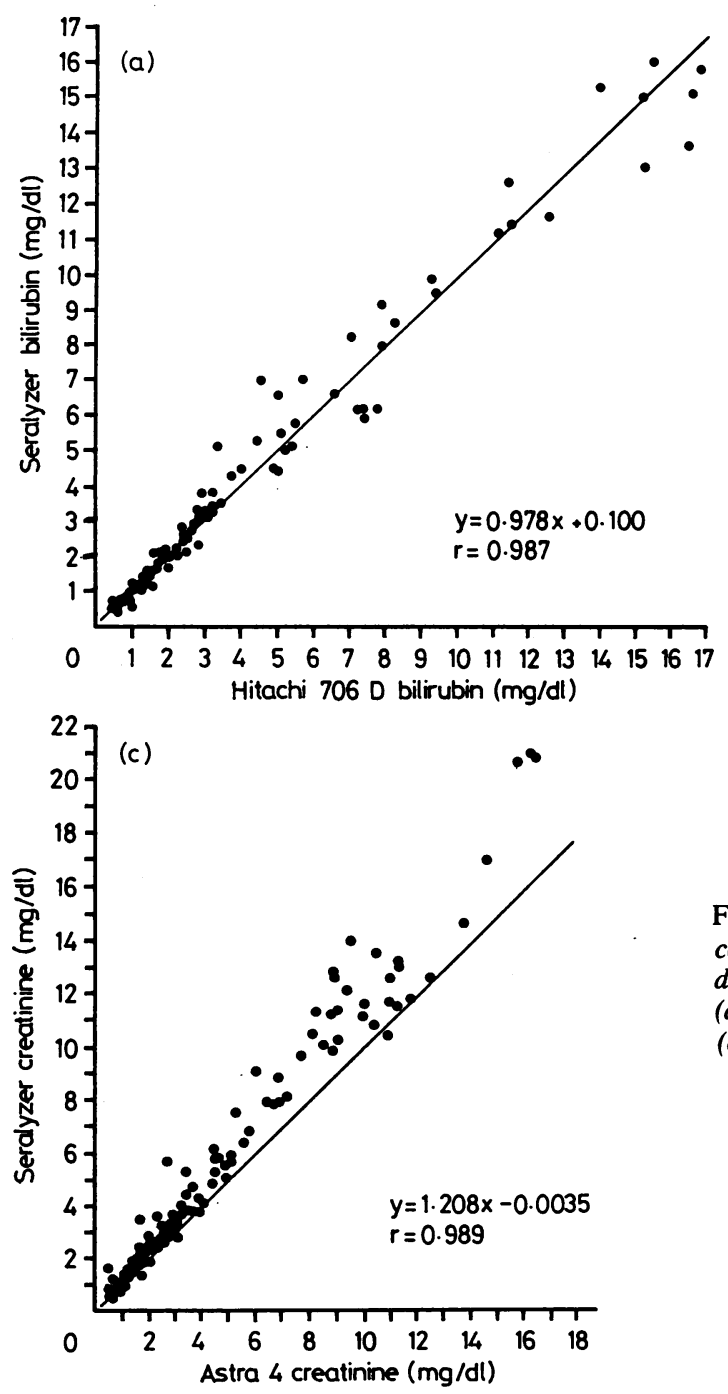

Table 1 Bilirubin precision results obtained by the assay of triplicates of two control sera with each batch of patient samples

\begin{tabular}{|c|c|c|c|c|}
\hline & \multicolumn{2}{|l|}{ Seralyzer } & \multicolumn{2}{|c|}{ Hitachi $706 D$} \\
\hline & Control $A$ & Control $B$ & Control $A$ & Control $B$ \\
\hline $\begin{array}{l}\text { No of runs } \\
\text { No of assays } \\
\text { Mean* }(\mathrm{mg} / \mathrm{dl})\end{array}$ & $\begin{array}{l}21 \\
63 \\
0 \cdot 88\end{array}$ & $\begin{array}{l}21 \\
62 \\
5 \cdot 03\end{array}$ & $\begin{array}{l}21 \\
63 \\
0 \cdot 82\end{array}$ & $\begin{array}{l}21 \\
63 \\
4 \cdot 86\end{array}$ \\
\hline $\begin{array}{l}\text { Within run } \\
\text { SD } \\
\text { CV(\%) }\end{array}$ & $\begin{array}{l}0 \cdot 031 \\
3 \cdot 5\end{array}$ & $\begin{array}{l}0.19 \\
3.8\end{array}$ & $\begin{array}{l}0 \cdot 051 \\
6 \cdot 2\end{array}$ & $\begin{array}{l}0.07 \\
1.4\end{array}$ \\
\hline $\begin{array}{l}\text { Between run } \\
\text { SD } \\
\text { CV }(\%)\end{array}$ & $\begin{array}{l}0 \cdot 030 \\
3 \cdot 5\end{array}$ & $\begin{array}{l}0.40 \\
8.1\end{array}$ & $\begin{array}{l}0 \cdot 067 \\
8 \cdot 1\end{array}$ & $\begin{array}{l}0.12 \\
2 \cdot 5\end{array}$ \\
\hline $\begin{array}{l}\text { Overall } \\
\text { SD } \\
\text { CV(\%) }\end{array}$ & $\begin{array}{l}0 \cdot 043 \\
4 \cdot 9\end{array}$ & $\begin{array}{l}0.45 \\
8.9\end{array}$ & $\begin{array}{l}0.084 \\
10.2\end{array}$ & $\begin{array}{l}0 \cdot 14 \\
2.9\end{array}$ \\
\hline
\end{tabular}

*To convert from $\mathrm{mg} / \mathrm{dl}$ to $\mu \mathrm{mol} / \mathrm{l}$, multiply by $17 \cdot 1$.

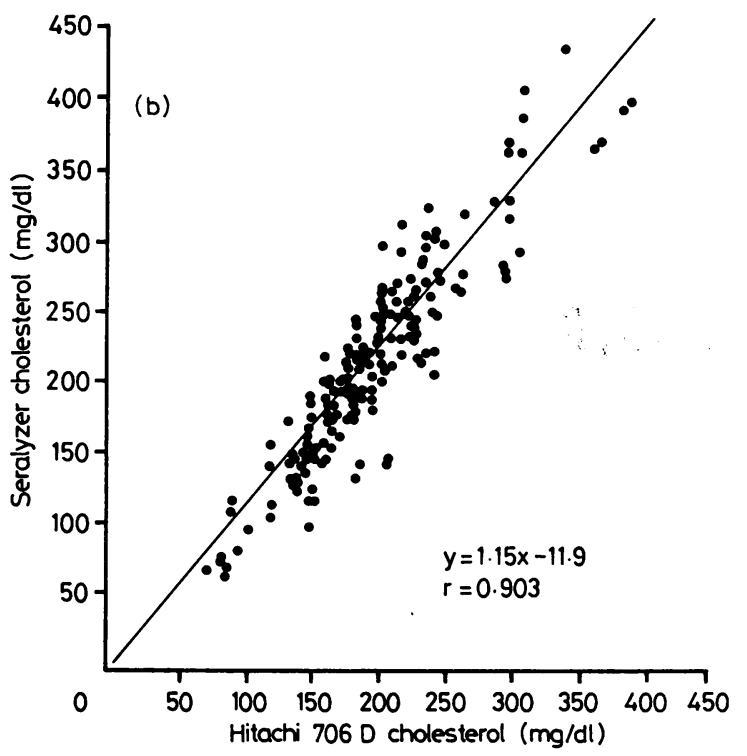

Fig. 1 Method comparison: scatter-plots of Seralyzer and comparative methods using clinical specimens from normal and diseased patients. Serum was used for the estimation of

(a) bilirubin and (b) cholesterol; plasma was used for the

(c) creatinine estimation. 
PROTOCOL

Within- and between-run precision data were obtained using serum pools and quality control sera at different analyte concentrations. Accuracy was assessed by the analysis of clinical specimens on the Seralyzer, relative to the routine comparative laboratory methods. Replicate precision of the clinical specimen assays was also determined. Serum was used for the bilirubin and cholesterol assays; plasma and serum were used for creatinine. The bilirubin test accuracy was assessed using adult specimens.

For trial purposes, the modules for all three chemistries were calibrated in units of $\mathrm{mg} / \mathrm{dl}$; consequently, all results are reported in these units. However, SI unit modules are now available.

\section{COMPARATIVE METHODS}

The comparative laboratory methods used were as follows:

Total bilirubin Hitachi 706D analyser-Caffeine/ sodium benzoate solubilisation, followed by diazotisation and the addition of alkali. This is based on the Jendrassik method. ${ }^{5}$

Cholesterol Hitachi 706D analyser-esterase action followed by cholesterol oxidase, and subsequent chromogenic reaction with 4-aminophenazone. ${ }^{6}$

Creatinine Beckman Astra 4 analyser-kinetic Jaffé reaction.?

\section{Results and discussion}

\section{Total bilirubin}

Precision data are shown in Table 1. These are based on triplicate measurements on two control sera in each batch of assays of clinical specimens. A graphical representation of the accuracy data, together with the regression parameters, are presented in Fig. 1. The Seralyzer total bilirubin system demonstrated an overall CV in the region of 5-9\% at the two levels studied, which is perfectly acceptable for clinical purposes and which falls within the current state-of-the-art requirements. Correlation studies demonstrated excellent agreement between the Seralyzer and the Hitachi methods, using sera from adult patients, over the range $0-17 \mathrm{mg} / \mathrm{dl}(0$ $300 \mu \mathrm{mol} / \mathrm{l}$ ), with a correlation coefficient of 0.99 ; the curve was linear, with a slope approaching the ideal. This method allows the use of neat serum, and will therefore provide a bilirubin measurement within less than two minutes: if the bilirubin concentration is above $7.5 \mathrm{mg} / \mathrm{dl}(130 \mu \mathrm{mol} / \mathrm{l})$, a $1 / 3$ serum dilution is required.

\section{Cholesterol}

Precision data from control sera are presented in
Table 2; replicate precision of clinical specimens demonstrated a within-run coefficient of variation of $6.5 \%$. Correlation of clinical specimens with the comparative method is presented in Fig. 1, with a correlation coefficient of $0 \cdot 9$. The cholesterol studies were performed on a 1/9 serum dilution. The results indicate very similar precision for both the Seralyzer and the comparative method at the levels studied. Comparison of the two methods using clinical specimens demonstrated good correlation; however, the observed slope and intercept reflect the fact that the comparative Hitachi method is known to underestimate cholesterol values by approximately $7 \%$ (JF Stevens, unpublished observations, 1982). There was very good agreement between duplicate cholesterol measurements performed on the Seralyzer; there were no gross outliers. Turbidity, often found in hyperlipaemic samples, and which interferes with non-protein precipitation methods, did not affect the reflectance method employed on the Seralyzer.

\section{Creatinine}

Within-run Seralyzer precision using a normal plasma pool can be seen from Table 3; between- and overall control sera precision data are presented in

Table 2 Cholesterol precision results-obtained by the assay of triplicates of two control sera with each batch of patient samples

\begin{tabular}{|c|c|c|c|c|}
\hline & \multicolumn{2}{|l|}{ Seralyzer } & \multicolumn{2}{|c|}{ Comparative } \\
\hline & Control $A$ & Control B & Control A & Control B \\
\hline $\begin{array}{l}\text { No of runs } \\
\text { No of assays } \\
\text { Mean* (mg/dl) } \\
\text { Within run }\end{array}$ & $\begin{array}{c}13 \\
39 \\
155 \cdot 3\end{array}$ & $\begin{array}{c}13 \\
37 \\
350 \cdot 4\end{array}$ & $\begin{array}{c}13 \\
39 \\
144 \cdot 9\end{array}$ & $\begin{array}{c}13 \\
39 \\
346 \cdot 2\end{array}$ \\
\hline $\begin{array}{l}\text { SD } \\
\text { CV }(\%)\end{array}$ & $\begin{array}{l}5 \cdot 7 \\
3 \cdot 7\end{array}$ & $\begin{array}{c}10 \cdot 8 \\
3 \cdot 1\end{array}$ & $\begin{array}{l}2 \cdot 6 \\
1 \cdot 8\end{array}$ & $\begin{array}{l}3 \cdot 4 \\
1 \cdot 0\end{array}$ \\
\hline $\begin{array}{l}\text { Between run } \\
\text { SD } \\
\text { CV }(\%)\end{array}$ & $\begin{array}{l}16 \cdot 8 \\
10 \cdot 8\end{array}$ & $\begin{array}{l}4.9 \\
1.4\end{array}$ & $\begin{array}{c}11 \cdot 8 \\
8.1\end{array}$ & $\begin{array}{r}11 \cdot 9 \\
3 \cdot 5\end{array}$ \\
\hline $\begin{array}{l}\text { Overall } \\
\text { SD } \\
\text { CV }(\%)\end{array}$ & $\begin{array}{l}17 \cdot 8 \\
11 \cdot 4\end{array}$ & $\begin{array}{r}11.8 \\
3.4\end{array}$ & $\begin{array}{r}12 \cdot 1 \\
8 \cdot 3\end{array}$ & $\begin{array}{r}12.4 \\
3.6\end{array}$ \\
\hline
\end{tabular}

${ }^{*}$ To convert from $\mathrm{mg} / \mathrm{dl}$ to $\mathrm{mmol} / \mathrm{l}$, multiply by 0.026 .

Table 3 Seralyzer creatinine within-run precision using replicates of "normal" plasma pools assayed on three consecutive days

\begin{tabular}{lccc}
\hline & Day 1 & Day 2 & Day 3 \\
\hline n & 10 & 10 & 10 \\
Mean (mg/dl)* & 0.68 & 0.82 & $1 \cdot 53 \dagger$ \\
SD & 0.042 & 0.042 & 0.048 \\
CV $(\%)$ & 6.2 & $5 \cdot 1$ & 3.15 \\
\hline
\end{tabular}

${ }^{*}$ To convert from $\mathrm{mg} / \mathrm{dl}$ to $\mu \mathrm{mol} / \mathrm{l}$, multiply by 88.4 $\dagger$ Different pool. 
Table 4 Creatinine precision results-obtained by the assay of triplicates of three control sera with each batch of patient samples

\begin{tabular}{|c|c|c|c|c|c|c|}
\hline \multirow[b]{2}{*}{ Control } & \multicolumn{3}{|c|}{ Seralyzer } & \multicolumn{3}{|l|}{ Astra } \\
\hline & $\boldsymbol{A}$ & $B$ & $C$ & $A$ & $B$ & $C$ \\
\hline $\begin{array}{l}\text { Between run } \\
\text { Mean }(\mathrm{mg} / \mathrm{dl})^{*} \\
\text { SD } \\
\text { CV }(\%)\end{array}$ & $\begin{array}{l}1 \cdot 21 \\
0 \cdot 14 \\
11 \cdot 3\end{array}$ & $\begin{array}{l}3.01 \\
0.21 \\
7.0\end{array}$ & $\begin{array}{l}6 \cdot 38 \\
0 \cdot 36 \\
5 \cdot 2\end{array}$ & $\begin{array}{l}1 \cdot 01 \\
0 \cdot 09 \\
8 \cdot 8\end{array}$ & $\begin{array}{l}2 \cdot 22 \\
0 \cdot 22 \\
9 \cdot 8\end{array}$ & $\begin{array}{l}5 \cdot 04 \\
0.27 \\
5 \cdot 4\end{array}$ \\
\hline $\begin{array}{l}\text { Overall } \\
\text { SD } \\
\text { CV (\%) }\end{array}$ & $\begin{array}{c}0.17 \\
13.9\end{array}$ & $\begin{array}{l}0.26 \\
8 \cdot 6\end{array}$ & $\begin{array}{l}0 \cdot 49 \\
7 \cdot 1\end{array}$ & $\begin{array}{l}0.05 \\
5 \cdot 1\end{array}$ & $\begin{array}{l}0.09 \\
4.5\end{array}$ & $\begin{array}{l}0.09 \\
2.0\end{array}$ \\
\hline
\end{tabular}

*To convert from $\mathrm{mg} / \mathrm{dl}$ to $\mu \mathrm{mol} / \mathrm{l}$, multiply by 88.4

Table 4. Correlation against the comparative Astra-Jaffé assay for plasma specimens is demonstrated in Fig. 1, with a correlation coefficient of 0.99 , while the linear regression parameters using plasma $(y=1.208 x-0.0035)$ and serum $(y=$ $1 \cdot 02 x+0 \cdot 12)$ were similar. The Seralyzer creatinine system was designed for use with serum, and has been demonstrated elsewhere to perform well with this fluid. However, since plasma is used extensively in the UK, it was felt useful also to examine this tissue fluid; therefore, the principal data are based on the use of plasma. The agreement on clinical plasma specimens between the Seralyzer and the comparative creatinine methods was good, with a correlation coefficient of 0.99 ; however, the slope of 1.2 obtained with plasma was the result of a problem associated with the trial calibrators, which has since been rectified. Serum specimens also demonstrated excellent correlation with the Astra method $(r=$ 0.995). Creatinine performance was also assessed briefly using serum and plasma specimens from the same patient; identical results were obtained from both types of specimen. This method can give a rapid indication of renal function in $30 \mathrm{~s}$ using undiluted serum or plasma.

\section{General}

In general, the Seralyzer system has proved to be simple and easy to use, giving accurate and precise results. The system has been reliable and the precision is such that the operator can have confidence in using only a single result, rather than the need to perform duplicate estimations. Raised concentrations of ascorbic acid may decrease Seralyzer choles- terol values; Seralyzer creatinine values may be increased by the presence of bilirubin, while haemolysed or other highly coloured specimens may also interfere with this test. However, no instances of interference with any of the three Seralyzer systems were demonstrated during these studies.

Two of these chemistries do not require sample dilution, therefore enhancing simplicity and rapidity of estimation. Although the cholesterol system requires sample dilution, the pipetter/diluter supplied with the system simplifies this procedure.

In keeping with good analytical practice, quality control samples should be run with each batch of analyses. Assigned values for the Seralyzer chemistries are now incorporated in the package inserts for many of the commercial quality control materials.

Very encouraging results have been produced from these studies. There is, therefore, every reason to believe that for the trained operator, the Seralyzer system can be used with confidence as a "Stat" analyser in hospital laboratories, the private sector, or established General Practitioner centres.

Grateful acknowledgements are due to the Courtauld Institute of Biochemistry of the Middlesex Hospital Medical School, London; and Ames Division, Miles Laboratories Limited.

\section{References}

' Thomas L, Appel W, Storz G, Plischke W. Determination of blood constituents with dry reagent carriers. Deutsch Med Wochenschr 1981;106:1091-4.

${ }^{2}$ Stevens JF, Newall RG. Application of reflectance spectroscopy to the estimation of uric acid and glucose: an evaluation of the Ames Seralyzer. J Clin Pathol 1983;36:9-13.

${ }^{3}$ Karmen A, Lent R, Clark LW, Chang ES. Clinical evaluation of Strip test for bilirubin in serum measured by Ames Seralyzer reflectance photometer. Clin Chem 1980;26:989-90.

${ }^{4}$ Zipp A. Development of dry reagent chemistry for the clinical laboratory. J Aut Chem 1981;3:71-4.

5 Jendrassik L, Grof P. Simplified photometric methods for the determination of the blood bilirubin. Biochemische Zeitschrift 1938;297:81-9.

- Schettler G, Nussel E. Massnahmen zur Prävention der Arteriosklerose. Arbeitsmed Sozial Med Praventivmed 1975;10:25-9.

' Bartels H, Böhmer M, Heierli C. Serum Kreatininbestimmung ohne Enteweissen. Clin Chim Acta 1972:37:193-7.

Requests for reprints to : Dr JF Stevens, St Stephen's Hospital, Chelsea, London, SW10 9TH, England. 